\title{
Editorial \\ Universitas Psychologica: Pan-American Journal of Psychology, 10 años de cambio canstante en la gestión editorial y de contenidos
}

La revista Universitas Psychologica cumple este año los primeros diez años. En este camino hemos tenido transformaciones significativas y profundas, que nos han llevado a cambiar de formato en papel y a transformar la propuesta en la web, la cual ha combinado un desarrollo estético con el sistema de gestión de contenidos del Open Journal System(OJS). Esta web ha generado dos artículos publicados donde mostramos cómo nuestra propuesta es un modelo de portal web de revista para el mundo (en http://journals.sfu.ca/src/index. $\mathrm{php} / \mathrm{src} /$ article/viewFile/20/35), uno de ellos en el portal de APA (http://www.apa.org/international/pi/2009/12/pan-american-journal.aspx). La publicación de estos artículos parece indicarnos que vamos por el camino adecuado. Otro de los indicadores es la inclusión de la revista en los sistemas ISI-WoS y Scopus, que ahora nos entregan información sobre los usos de nuestros contenidos expresados en citas.

El éxito y la visibilidad internacional que ha ganado Universitas Psychologica también ha traído dificultades, en lo que he llamado una "crisis de éxito". Esta crisis se ha reflejado en un incremento exponencial en el número de artículos en los últimos dos años - más de 1200 artículos, y pasamos de publicar 2 números al año con 30 artículos, a 60 artículos al año en tres números anualmente. Ello ha implicado, en primer lugar, la búsqueda de pares por todo el mundo iberoamericano, y por otro la multiplicación de los textos en inglés y portugués, con lo cual se ha hecho más compleja la gestión de contenidos.
Por otro lado, la pluralidad conceptual, metodológica, y de áreas, nos ha generado más dificultades por cuanto no contamos con una masa crítica de pares en este amplio espectro. Adicionalmente, los pares en Iberoamérica tienen diversas competencias, lo cual ha significado contrastes entre evaluadores, además de no contar con tiempos que nos proponemos para responder a los autores. Lo anterior ha suscitado, en más de una ocasión, molestias entre los autores que, aun cuando justificadas, parecen desconocer las realidades de la dinámica académica iberoamericana. El reto es optimizar los tiempos de búsqueda y aseguramiento de pares evaluadores y el mejoramiento de la calidad de las evaluaciones y la respuesta a los autores. Seguiremos pidiendo paciencia: esta dificultad no será resuelta en el corto plazo, si queremos someter todos los artículos que nos llegan a evaluación con los aprendizajes que esto conlleva a toda nuestra comunidad.

Universitas Psychologica además tiene, como hemos mencionado en otra editorial, el reto de consolidarse como una publicación de referencia en nuestra comunidad, lo cual no puede lograrse si no con la colaboración de todos los autores que generen una mayor cantidad de citas a los trabajos de la revista, y de una mejor calidad. Los indicadores de SJR de SCIMAGO derivados de los datos de Scopus y los datos preliminares de ISI WoS que esperamos aparezcan en el JCR en el transcurso del año, muestran un incremento importante en citas: pasamos de 4 citas en 2008 a 30 citas en el año 2009. El SJR local parece mostrar que estamos 
siendo cada vez más reconocidos por nuestra comunidad como una revista de calidad. Adicionalmente, entendemos que los autores comprenden que publicar en ingles incrementa la probabilidad de ser leídos en el mundo entero y hoy Universitas Psychologica está siendo consultada por el mundo entero. Sin embargo, es evidente que no basta con publicar en este idioma, sino que es necesario comunicarle a nuestros pares sobre nuestros artículos. Y que el reto para quienes publican en español y portugués es que las comunidades en estos dos idiomas usen los contenidos publicados en los mismos. Entiendo que esto es también un proceso de cambio cultural que tomará tiempo, pero estamos acometiendo las acciones necesarias para fortalecer este camino en la región y simultáneamente conseguir la meta de consolidarnos como una revista internacional.

Debo mencionar también que en estos diez años, la revista además se ha comprometido con los sistemas de acceso abierto desarrollados en la región, tales como SciELO (http://www.scielo.org. co), Redalyc (http://redalyc.uaemex.mx), Pepsic (http://pepsic.bvsalud.org) y la BVS Psicología (http://www.bvs-psi.org.co). En estos años como editor de Universitas Psychologica, he sido Miembro electo por votación de la comisión Scielo Colombia en el periodo 2008-2009, he acompañado el desarrollo de la Biblioteca virtual en Psicología (BVS-PSI), y primer director del portal Redalyc en psicología (Psicoredalyc, iniciativa acompañada por la FIAP [Federación Iberoamericana de Asociaciones de Psicologia]), que hoy cuenta con 60 revistas de psicología de todo el continente. A finales del año 2010 fui nombrado presidente- coordinador del comité asesor internacional del sistema Redalyc .

También es necesario mencionar que en esta línea de consolidar redes de visibilidad en Iberoamérica, hemos estado organizando los encuentros iberoamericanos de editores de revistas de psicología y la reciente red de revistas de psicología de Iberoamérica. Estoy seguro de que estas acciones contribuirán a fortalecer nuestra comunidad académica.

Entendemos que tenemos mucho que aprender y cambiar que hay múltiples acciones que debemos asumir para continuar con la confianza en la calidad y el mejoramiento permanente de nuestra revista que nuestros autores y lectores nos otorgan en forma creciente.

Por último, deseo destacar el trabajo de los coordinadores editoriales y de los equipos editoriales, comité editorial, científico, de árbitros, de los estudiantes voluntarios, y de los equipos de la Editorial Javeriana. En especial sin el trabajo incondicional, exhaustivo, riguroso de los coordinadores la revista (primero Camilo Hurtado y luego Luis Manuel Silva), no tendría la calidad que hoy reconoce en forma creciente la comunidad internacional.

Felices 10 años de existencia para Universitas y gracias a todos por este camino de confianza que hemos recorrido y por el que seguiremos transitando.

Wilson López-López

Editor 


\section{Editorial \\ Universitas Psychologica: Pan-American Journal of Psychology, 10 años de cambio canstante en la gestión editorial y de contenidos}

Our journal is turning 10 years old in 2011. During this period, we have experienced deep and significant transformations, that have led us to change our printed format and to modify the Web proposal, which has merged an aesthetical development with the Open Journal System (OJS) for content management. This web has generated two published articles, where we show how our proposal is a model for journal websites all around the world (the articles can be found in http://journals.sfu. $\mathrm{ca} / \mathrm{src} /$ index.php/src/article/viewFile/20/35 and http://www.apa.org/international/pi/2009/12/panamerican-journal.aspx). The publication of these articles suggest that we are going the right way. Another indicator is the coverage of the journal in the ISI WoS and Scopus systems, which now deliver information about the way our contents are used, expressed in citations.

The success and international visibility achieved by Universitas Psychologica has also brought some difficulties - what I call a "success crisis". This crisis has been seen in the exponential increase in article submissions - over 1200 in the past two years, and in the need to grow from two issues per year, 30 articles, to three issues with 60 articles per year. The situation has demanded that we look for peer reviewers all over the Iberoamerican world, and has brought about an increase in articles written in English and Portuguese, which has made content management more complex.

On the other hand, conceptual, methodological, and thematic plurality, has given us something else to worry about, since we do not still have a critical mass of peer reviewers. Moreover, the reviewers in Iberoamerica have different skills, which has led to divergent opinions, and this has, in turn, had an influence on reviewing times - we have not been able to provide timely reviews in some cases. Of course, and more than once, authors have expressed their inconformity with the situation, despite enough justification of the realities of Iberoamerican academic dynamics, which they sometimes fail to acknowledge. The challenge for us is to optimize peer reviewer search and invitation times, and to increase the quality of the assessments and the answers to the authors. We will continue to beg for your patience: this problem will not be solved in the short term, if we want to take every article to peer reviewing, with the associated learnings for our community.

As we have previously mentioned, Universitas Psychologica also has the challenge of consolidating itself as a referential journal in our community, which cannot be achieved by means different than the collaboration obtained from all the authors, in terms of an increase in citations to the Journal. The Scimago SJR indicators stemming from Scopus and the preliminary data from ISI WoS, that we expect to receive in the new JCR to be published this year, show an important increase in citations: we went from four citations in 2008, to 30 in 2009. The Local SJR seems to suggest that our community is giving us more recognition as a quality journal. Moreover, we see that authors understand that publishing in English increases the likelihood of getting their papers read worldwide, and today, 
Universitas Psychologica is being consulted all over the world. Nevertheless, it is evident that it is not enough to publish in English, but that it is also important to tell our peers about our articles. And the challenge for those who publish in Spanish and Portuguese is that communities publishing in these two languages use the contents written in both languages. I understand that this is also a process of cultural change that will take time, but we are also carrying out the actions necessary to strengthen this path in the region, and simultaneously to consolidate ourselves as an international journal.

I must also mention that, during the past ten years, the journal has committed itself to cooperating with open access systems developed in the region, such as SciELO (http://www.scielo.org. co), Redalyc (http://redalyc.uaemex.mx), Pepsic (http://pepsic.bvsalud.org) and the Virtual Health Library - Psychology (http://www.bvs-psi.org.co). In these years as an editor for Universitas Psychologica, I have been appointed as a member of the SciELO Colombia committee (2008-2009), I have accompanied the development of the Virtual Health Library - Psychology (BVS Psicología), and I have been appointed as the first director of the Redalyc Psychology Portal (Psicoredalyc), an initiative sponsored by the FIAP (Iberoamerican Association of Psychology Federations), covering over 60 journals from the whole continent. At the end of 2010, I was appointed President-Coordinator of Redalyc's International Advisory Committee.
It is also noteworthy that, in this line of consolidating visibility networks in Latin America, we have been carrying out the Iberoamerican Psychology Journal Editors Meetings, and we have created the Iberoamerican Psychology Journals Network. I am sure that these actions will contribute to the strengthening of our academic community.

We understand that we still have much to learn, and that there are several actions that we need to perform in order to continue to benefit from your confidence and to continuously improve our journal.

Last, I want to stress the collaboration of the editorial coordinators and teams; of the scientific, editorial, and peer-reviewer committees, of the volunteer students, and the people from the Javeriana Publishing house. Specially, the unconditional, exhaustive, and rigorous work of the coordinators (Camilo Hurtado and then Luis Manuel Silva), without whose work, the journal would not have the quality that is being recognized by the international community.

Happy 10 years for Universitas Psychologica, and thank you all for these road of confidence that we have been walking.

Wilson López-López

Editor 